\title{
Can't get there from here: attainable distance, sustainable intensification and full-scale technical potential
}

\author{
Andrew P. Barnes ${ }^{1}$
}

Received: 31 May 2014/Accepted: 17 December 2015/Published online: 20 January 2016

(C) The Author(s) 2016. This article is published with open access at Springerlink.com

\begin{abstract}
Full-scale technical potential provides a clear horizon for agricultural technology policy to meet the dual and urgent challenge of meeting food security and minimising the effects of climate change. A common stated goal is to double food production by 2050 to meet the needs of 9 billion people. The frontier of full-scale technical potential embodies this goal and provides a panacea for policy makers. However, the pathway between the present adoption of technologies towards this frontier is paved with some hazards which may be insurmountable. We develop a conceptual framework based on adoption levels of technology. The key criteria between current and potential adoption of technologies is the role of enablers, that is interventions which create changes in structural, distributional, technical, social and behavioural cultures. Policy must find optimal mixtures of regulation and voluntary mechanisms to fully encourage uptake of technologies and shift current adoption to meet full-scale technical potential. A range of technologies can be aligned with sustainable intensification and are examined in terms of this enabler framework. Further examination of the framework allows us to conclude that full-scale technical potential will never be achieved due to the stochastic nature of agricultural production, the diversity of motivations and institutional structures operating within food supply chains, as well as unbalanced cost-effectiveness criteria. We argue that sustainable intensification may provide a direction of travel for attaining food security but its poor
\end{abstract}

Andrew P. Barnes

Andrew.Barnes@sruc.ac.uk

1 Land Economy, Environment and Society Group, Research Division, West Mains Road, Edinburgh EH9 3GJ, Scotland, UK conception, limited acceptability and understanding amongst the communities of interest lead to over-optimism in determining the journey to this final destination.

Keywords Sustainable intensification · Full-scale technical potential · Agriculture

\section{Introduction}

Increasing volatility of supply and the consequences on hunger and malnutrition are high-profile targets for national and international food policy (FAO 2010a, b). This makes attaining food security, whilst also managing and reducing greenhouse gas (GHG) emissions, a particularly intractable problem for policy makers (Gregory et al. 2005; Godfray et al. 2010; OECD 2011). This has led to repeated calls for technological investments to enable, what Vermeulen et al. (2012) refer to, 'accelerated adaptation'. These technological options offer a series of 'exit' pathways that require a rapid accumulation of science into practical solutions and, implicitly, the development of new knowledge frameworks to mitigate volatility in supply. Such pathways, involving significantly increased investment, as well as practices and policies should, when effectively transferred to farming systems, lead to improved food security, farming livelihoods and mitigation of environmental impacts (Tilman et al. 2002; FAO 2011).

Employing technology to manipulate biophysical relationships has proven a worthwhile use of public resources (Alston et al. 2000; Hurley et al. 2014). However, Smith et al. (2007) argues that in addition to biological and physical barriers, there are economic and social barriers to meeting full-scale technical potential. They estimated that less than $35 \%$ of the total biophysical potential for 
agricultural mitigation is likely to be achieved by 2030 due to economic constraints. In the light of recent scientific advances which can release more yield and nutritional quality from staple crops (Ye et al. 2000; Barraclough et al. 2010; Parry et al. 2011), the enablers for releasing accelerated adaptation to meet these dual needs should be further scrutinised. This is because, in addition to standard accounting approaches to understanding economic barriers, they illuminate the level of political willingness to intervene within the agricultural sector.

Policy plays a significant role in both enabling and restricting transition, through funding of research and development, provision of information, and directing regulation to induce innovation or restrict activity within the private sector. One high-profile example is the focus on nitrogen use management to create resource use efficiencies (Barnes et al. 2013). Resource use efficiency is part of efforts towards achieving sustainable intensification within agriculture, and the purpose of this paper is to examine the role of sustainable intensification in meeting full-scale technical potential through the lens of policy potential.

The aims of this paper are twofold: firstly to provide a normative framework which extends the Smith et al. (2007) concept to allow the gap between full-scale technical potential and actual potential to be conceptualised, and secondly to examine sustainable intensification as a means to overcome the gap between current and full-scale technical potential. This second task is clearly hampered by a lack of focus in the definition of sustainable intensification (Barnes and Poole 2011; Franks 2014) and where it sits within the schema of technological solutions. Accordingly, the next section focuses on how to identify sustainable intensification technologies through a review of the policy and research literature. This is followed by a conceptual schema to measure realised and possible technological potential, which we refer to as 'attainable distance'. Finally, technologies which aim to achieve sustainable intensification are highlighted using an intervention ladder approach, to assess their potential to reduce this distance and discussions and policy conclusions are drawn.

\section{Sustainable intensification at the nexus of climate change and food security}

A range of future land use scenarios have inferred that resource scarcity, compounded by increasing variability from climate drivers, will negate the output goals required from future global food production systems. Agricultural economies have been typified by high rates of productivity growth, which are underpinned by advances in technology, as well as structural intensification over time to engender growth in input usage. Whilst this growth has been impressive, there is a great deal of regional variation and recent evidence shows a slowdown in growth rates of productivity (Fuglie et al. 2012). In addition, forecasted future productivity growth will be affected by increasing constraints on the input side, principally through increasing competition of land for other uses (Rosegrant et al. 2008; Smith et al. 2010), through scarcity in both the quantity and quality of water and nutrient resources (Matson et al. 1997; Barnes 2002; Cordell et al. 2009) and through growing variability in output potential, through climate-related disease effects (Rosenzweig et al. 2001; Tilman et al. 2002; Olesen and Bindi 2002; Oerke 2006). The challenge to simultaneously raise yields, increase the efficiency by which inputs are used and also reduce the negative environmental effects of food production has led a large body of scientific and policy literature to coalesce around the concept of sustainable intensification (Baulcombe et al. 2009; Foresight 2011). There are numerous definitions but Pretty et al. (2011) determine sustainable intensification as:

Producing more output from the same area of land while reducing the negative environmental impacts and at the same time increasing contributions to natural capital and the flow of environmental services.

Interpretations of what is sustainable intensification (SI) much like definitions of sustainability (e.g. Pezzey 1997) can differ; however, land scarcity seems to be the common denominator in most arguments for its application within agriculture. SI, therefore, tends to coalesce around technological solutions to overcome scarce land constraints (see Baulcombe et al. 2009; Beddington et al. 2012). Whilst in principle the production of more yield per unit of area is generally accepted, responses to sustainable intensification as a technological solution to future food security needs have been quite emotive (Misselhorn et al. 2012; Hanspach et al. 2013; Scarpellini et al. 2013). Perhaps in response to this, Garnett et al. (2013) propose sustainable intensification as only part of the food security solution alongside demand management, reduction in food waste, and family planning as well as governance structures for land. Hence, in conjunction with wider systemic issues, the adoption of land-saving-type technologies will be an aspect of meeting the demands of volatile food production systems in the future.

Arguably a pragmatic, farm-led, approach to sustainable intensification can be found in Elliott et al. (2013) and Barnes and Thomson (2014). These both adopt concepts of the production possibility frontier for farms to shift in dual directions. Barnes and Thomson (2014) equate this with eco-efficiency approaches under a fixed land constraint. They modify the return-risk framework outlined in Keating et al. (2010) and apply the term 'social risk' to 
encapsulate the higher probability of damage to environmental, economic and social capital from intensification. Figure 1 considers a range of pathways to the farm.

The thick line represents the current technology frontier, and a farm at point $A$, operating at its optimal technical and allocative efficiency, can move along this to increase yield. Technology is therefore the major constraint to further improving yield, and the only option available at this time point is to intensify production, that is move from point $\mathrm{A}$ to $A_{1}$ to $A_{2}$. As more resources are needed to produce more yield, this increases social risk as the rise in input intensity leads to higher probability of potential damage. Moving from $A$ to $A_{1}$ has a higher risk of not 'maintaining or enhancing natural capital' (Pretty 2008). Even more significant is the movement along the frontier to point $\mathrm{A}_{2}$, whereby the change in yield is significantly less than the increase in social risk associated with intensifying.

A new technology is represented by the dotted line where a farm at point (A) can increase yield by shifting up to point (B) relative to current intensity levels. Here yield has increased with no increase in social risk. However, moving along the new frontier $\left(B_{1}, B_{2}\right)$ increases yield and increases social risk. Ultimately, therefore, this figure shows that the probability of social risk increases as farms intensify. Sustainable intensification could therefore be seen as a shift upwards to obviate the per unit increase in social risk for a farm on the frontier. Implicitly, adoption of new techniques and technologies is the basic requirement for meeting sustainable intensification.

This leads to the appropriate choice set of technologies which enable a shift upward to improve the relationships between inputs and outputs and negate social risk as farms intensify. Ultimately, a range of options will become available at the farm level for sustainably improving input- output ratios and meeting price demands but which are also longer-term and permanent investments which also minimise the volatility of production.

For those farms not on the frontier, the non-adoption of sustainable technologies across farms is reflective of the range of economic and behavioural barriers. Hence, the most significant tier of sustainable intensification, which has not been discussed in detail, is the 'scaling out' of technologies across a region and along a supply chain. This exposes a sustainable technology to behavioural differences across farming and between supply chain actors, including consumers (Haden et al. 2012; Barnes and Toma 2012; Islam et al. 2013; Fischer et al. 2013), economic barriers (Anderson et al. 2001; Antle and Diagana 2003; Prokopy et al. 2008; Baumgart-Getz et al. 2012) and biophysical barriers (Chavas and Holt 1990; Brain et al. 2014). These barriers are also determined by the type and amount of intervention within the sector, which in turn is characterised by the governance structure of a particular region. Given the complexity of this system, the next section introduces the concept of attainable distance to provide a framework for understanding the distances between present uptake and full technical potential.

\section{The concept of attainable distance}

\section{Modelling full-scale technical potential in GHG abatement}

In Fig. 2 we use GHG as an example of social risk abated. This is reflective of the current uptake of the available technology (current adoption frontier) and the full set of technologies available (full-scale technical potential).
Fig. 1 Return-risk framework applied to sustainable intensification

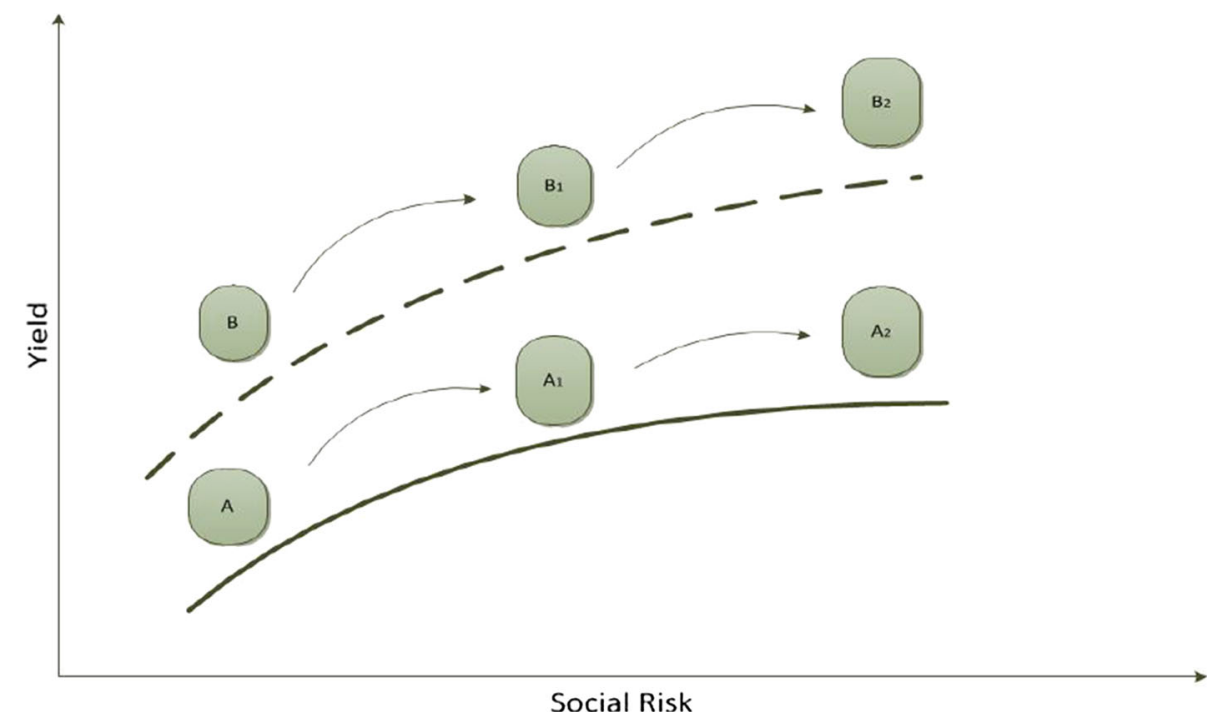

Social Risk 
Fig. 2 Full-scale technical potential, full policy potential and current adoption

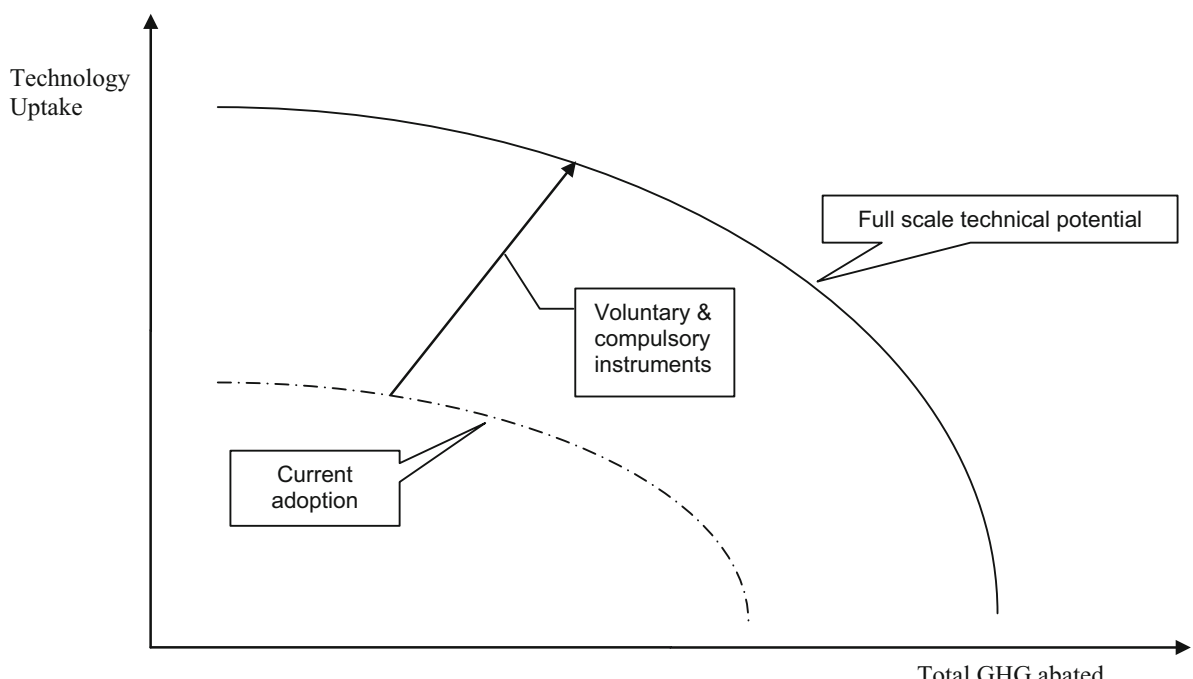

Total GHG abated
The distance between these frontiers reflects the potential to move current adoption closer to the full-scale technical potential. For instance, Vermeulen et al. (2012) argue for a range of market based and voluntary measures to meet GHG abatement. The role of policy is therefore to implement a range of interventions to encourage the adoption of techniques which shift the frontier forward, or penalise practices which hinder this movement. These policies encapsulate a broad range of incentives, such as investment in research and extension services, or regulation to encourage market based innovations. These instruments could also be direct, with respect to mitigation technologies, or indirect, with respect to providing the environment to encourage adaptation, e.g. through increasing advisor training in reducing risk from climate variability.

Current adoption can be represented by the sum of presently adopted technologies and their level of GHG emissions abated within a particular region. This provides a baseline for understanding potential. Current abatement $\left(Y_{c a}\right)$ is therefore the sum of a set $(n)$ of available technologies (a) applied to a specific unit (ha, or livestock units) within a particular region. Furthermore, within the farming system, there will be an additive effect from interaction or replacement between the sets of adoption technologies operating within the farm in the current time period, for example nitrogen efficiency measures coupled with more efficient feed mixes. Hence, an interaction term which reflects this additional effect and is related to a subset of current technologies adopted needs to be included within the estimation.

Clearly, the frontier between current adoption and fullscale technical potential will shift over time when the adoption of newer technologies becomes more feasible and cost-effective. These can be denoted as the $(\mathrm{m})$ set of new technologies $(p)$ and will be additional to the current adopted set above or replace those currently adopted (reducing the $n$-set of current adoption). As above we take an additional subset of technologies $(l)$ which defines the additive effect of including a number of potential technologies together within the farm system.

A further effect may emerge from the interaction between current and potential technologies to determine full-scale technical potential. It would be expected that replacement of current with potential technologies would increase emission reduction potential, and hence this term is positive. Similarly, the addition of potential to current technologies would also positively shift the frontiers upward. These interaction effects are determined by adding another term which reflects the relationships between current and potential technologies. The frontier for full-scale technical potential $\left(Y_{\mathrm{AP}}\right)$ can be written as the sum of currently adopted technologies $(a)$ plus potential adoption technologies $(p)$, plus interaction terms for current, potential and current by potential technologies.

$$
\begin{aligned}
Y_{\mathrm{AP}}= & \sum_{i=1}^{n} \alpha_{1 i} a_{i}+\sum_{i=1}^{r} \beta_{1 i} a_{i}+\sum_{j=1}^{m} \alpha_{2 j} p_{j}+\sum_{j=1}^{l} \beta_{2 j} p_{j} \\
& +\sum_{k=1}^{q} \beta_{3 k} a p_{k}
\end{aligned}
$$

where $Y_{\mathrm{AP}}$ is full-scale technical potential, $a_{i}$ is the $i$ th technology adopted, $\alpha_{1 i}$ is the parameter effect on abatement of the $i$ th current technology adopted, $\beta_{1 i}$ is the interaction effect on abatement of adding the $i$ th technology to the farm system, $r \subseteq n$. ( $r$ is a subset of $n$ technologies), $p_{i}$ is the $i$ th potential technology adopted, $\alpha_{2 i}$ is the parameter effect of the $i$ th potential technology adopted, $\beta_{21}$ is the interaction effect of adding the $i$ th technology to the farm system, $1 \subseteq m$ ( 1 is a subset of $m$ potential technologies), $a p_{k}$ is the kth technology adopted (where 
$k=1 \ldots q), \beta_{3 k}$ is the interaction effect of adding the jth potential technology to the current $i$ th technology, $q \subseteq(n+m)$ (q is a subset of $m+n$ technologies)

However, whilst mitigation can be modelled, adaptation will also occur. So far the modelling framework presented has been relatively static, all be it inferring two discrete time periods between current and potential adoption. In order to model adaptation a more dynamic temporal element is needed within the framework. More specifically, the modelling above does not include any stochastic variance terms. Weather disturbances will have an impact on the effectiveness of the technologies to mitigate GHG emissions, and market factors will affect short-term application, e.g. feed mixtures and long-term investment for farmers. These effects are not trivial, for example GHG emissions associated with agriculture in Scotland have fallen by $27 \%$ between 1990 and 2010 due to reduced livestock numbers and arable conversion to grassland (Committee on Climate Change 2012). Some of this relates to a response to rising feed costs and lowering prices of livestock products.

Adjusting the framework for adaptation can be modelled through the addition of a stochastic variance term (ع) which will capture the variability in potential not modelled by uptake of technologies. Adaptation can therefore be imputed through minimising fluctuation in yields or productivity. Therefore, the relationship between the stochastic variance term and on-farm adaptation is reflective of how adapted a system is to these variance effects. Accordingly, a dummy variable could be added to account for different categories of adapted system $\left(D_{1}\right)$. This will have a direct effect on both the potential for GHG abated (as higher categories of adaptation will both minimise stochastic error and increase the abatement potential for technologies currently and potentially adopted), inferred through the parameter effect $\left(\beta_{4}\right)$.

$$
\begin{aligned}
Y_{A P}= & \sum_{i=1}^{n} \alpha_{1 i} a_{i}+\sum_{i=1}^{r} \beta_{1 i} a_{i}+\sum_{j=1}^{m} \alpha_{2 j} p_{j}+\sum_{j=1}^{l} \beta_{2 j} p_{j} \\
& +\sum_{k=1}^{q} \beta_{3 k} a p_{k}+\beta_{4 i} D_{1 i}+\varepsilon
\end{aligned}
$$

Increasing adoption and the consequent amount of GHG abated will be through a series of voluntary and compulsory interventions related to policy change (e.g. more restrictive regulation), institutional change (e.g. changes in banking and advisory structures for farmers) and behavioural change within the producers (e.g. acceptance and application of GHG saving techniques within the farming system). Increasing uptake of these technologies will either be encouraged or be distorted through regional level factors, such as legal and institutional constraints, e.g. restrictions in genetic modification (GM) or growth hormones; behavioural barriers, e.g. breaking habits towards nutrient application; and economic barriers, such as the significant capital cost for installing some technologies, e.g. anaerobic digestion. Conversely, these could be classified as institutional, economic and behavioural enablers if they can be changed to shift the current adoption frontier upwards and closer to the full-scale technical potential frontier. This is discussed below.

\section{Modelling enablers of full full-scale technical potential}

We define an $(s)$ set of enablers available to policy makers. The mixture of enablers will depend on the regional approach to intervention which will impact potential adoption. Accordingly, the uptake of current and potential technologies will have to be weighted $(w)$ by the sum of these enablers with respect to the level of compulsion (e.g. mandatory coverage of the agricultural area) and incentivisation (e.g. amount of payment applicable for a grant, willingness to adapt to long-term change) to encourage future adoption.

$$
\begin{aligned}
Y_{\mathrm{AP}}= & \sum_{i=1}^{n} \sum_{t=1}^{s} a_{1 i} \omega_{i t} a_{i}+\sum_{i=1}^{r} \beta_{1 i} a_{i}+\sum_{j=1}^{m} \sum_{t=1}^{s} \alpha_{2 j} \omega_{i t} p_{j} \\
& +\sum_{j=1}^{l} \beta_{2 j} p_{j}+\sum_{k=1}^{q} \beta_{3 k} a p_{k}+\beta_{4 i} D_{1 i}+\varepsilon
\end{aligned}
$$

That is, the frontier for full-scale technical potential $\left(Y_{\mathrm{AP}}\right)$ is equal to the effect of currently adopted technologies plus the effect of potential technologies $(p)$ weighted by the $(s)$ set of institutional, economic and behavioural enablers available in that region.

These weights will be defined by the political and economic system of a particular region. Hence, this is a qualitative term and also temporally distinct, as research and development policies evolve to meet societal issues. A parsimonious approach to understanding the suite of regionalised interventions is through a Nuffield Ladder approach (Nuffield Council on Bioethics 2007). This ladder ranks interventions in terms of the level and choice of control over production. Furthermore, the ladder infers the transaction costs of imposing these interventions and illustrates the potential consequences of these mechanisms (Rorstad et al. 2007). The spectrum of options range from 'no-choice', that is strict regulation on practices and technologies, to 'full-choice', namely no intervention to allow the market to determine the extent of change.

In reality a region will have a mixture of measures which could either compel or encourage uptake. Examples 
of eliminating choice options could relate to designation as a Nitrate Vulnerable Zone, which imposes restrictions on application and storage of nutrients, or mandatory crosscompliance from the CAP, to restrict or ban practices which could increase GHG emissions. More voluntary-based interventions could be the provision of information on nutrient management and herd health, support for uptake of carbon calculators or for organising producer groups focused on GHG abatement. Clearly, the more intrusive the mechanism on choice, the stronger the justification required to intervene as it will invariably incur more transaction costs and, also, possibly decrease voluntary willingness to adopt additive measures. For example Barnes et al. (2013) found that farmers in Scotland under regulatory Nitrate Vulnerable Zones were less willing to adopt voluntary water pollution mitigation measures compared to those outside the zones. Moreover, this is regionally specific as some countries historically favour more public support or regulation than other economies, a particularly high-profile example of this being differences in the use of genetically modified materials in food production (Hamprecht et al. 2005; Hagendijk and Irwin 2006; Tencalla 2006).

\section{Enabling sustainable intensification to meet full full- scale technical potential}

Sustainable intensification can be defined by both its technologies and its outcomes. Outcomes, as discussed above, are somewhat difficult to define aside from the global ambition for meeting future food demand sustainably, and this is determined by either a land-sharing or a land-sparing identity (e.g. Garnett et al. 2013; Hertel et al. 2014). There may be more clarity in identifying the techniques and technologies which could be implemented into the food supply chain in order to meet increased yield and sustainability of supply under fixed or diminishing land constraints. Accordingly, Table 1 provides examples of current and potential technologies which could be aligned with sustainable intensification and, along the horizontal axis, the enablers for shifting the frontier forward. These enablers have been itemised along a truncated Nuffield Ladder scale, showing interventions which range from regulation to voluntary adoption.

Ultimately, the mixture of regulatory and non-regulatory measures is critical in determining the cost-effectiveness of scaling out these technologies. In addition, from a supply chain perspective, there are numerous institutional and politico-legal barriers to adoption, not least the high levels of concentration and market influence of some players within the supply chain which would also need to be overcome to meet full-scale technical potential (Smith and Martindale 2010; Leat et al. 2011).

\section{Discussion}

The emergence of sustainable intensification in the 1990s in the developing country context seems wholly appropriate given the limited input base, the failure of the green revolution and a projected potential for significant output increases (e.g. Pretty et al. 2011). However, its more recent application to the developed country context has proven more contentious (see Barnes 2012; Hanspach et al. 2013). Agricultural systems within high-income countries exhibit a range of problems which are arguably centred on distribution and wastage, rather than the need for output expansion (Sage 2012; Whitehead et al. 2013). Accordingly, adoption of SI technologies to simultaneously produce more food and abate social risk may have negative effects on other policy aims towards consumption, trade, development and competition policy. Hence, appreciation of the trade-offs between these policies would seem a significant issue as higher-level nutritional and waste policies are in opposition to an expansionist food production policy. This reveals, perhaps, the need to regionalise SI at national, or sub-national, levels to accommodate achievable goals and outcomes for policy and to ensure acceptable rates of return for investment (see Barnes 2012).

Furthermore, implicit within the framework proposed is the farmer and their willingness to adopt sustainable technologies. Farmers, on the whole, respond more to financial incentives when aiming to meet ecological goals (Wilson and Hart 2000; Siebert et al. 2006; Guillem and Barnes 2013). This creates barriers for translating SI to enable change at the farm level, and indeed, may simply be a licence to produce regardless of wider sustainability effects (Tomlinson 2013; Maye and Kirwan 2013; Fish et al. 2013).

Within high-income countries incentives to adopt new technology are also muted through high subsidy regimes (Just and Zilberman 1983; Just and Pope 2002; Rehman et al. 2003). Stricter cross-compliance measures could meet some goals of SI, such as maintaining permanent pastures or ecological set-aside proposed in the latest round of CAP reform (European Commission 2013). These may be costeffective measures for increasing awareness of sustainability goals which would then lead to greater adoption of sustainable intensive technologies. Accordingly, translation of SI through technology, such as carbon audits, and the wider generation of cultural and social capital it brings may help create a shift towards full technical potential (Burton et al. 2008; Moran et al. 2013).

Assembling technologies under the sustainable intensification banner can be contentious as there are definitional boundaries on what SI is and what it offers the debate on food security, climate change and the natural and social 
Table 1 Farm uptake technologies related to sustainable intensification and enablers

\begin{tabular}{|c|c|c|c|}
\hline \multirow[t]{2}{*}{ Farm uptake technology } & \multicolumn{3}{|l|}{ Enablers } \\
\hline & Regulation & Fiscal measures & $\begin{array}{l}\text { Non-regulatory/non-fiscal/ } \\
\text { voluntary }\end{array}$ \\
\hline Nitrogen use efficiency & Ban chemical $\mathrm{N}$ & $\begin{array}{l}\text { Payment for uptake of } n \text {-use } \\
\text { planning }\end{array}$ & Expand advisory network \\
\hline Cover slurry stores & Set a quota for stocking levels & Offer capital grants & Carbon calculator \\
\hline Nitrification inhibitors & Restrictions at point of sale & Subsidise input cost & Carbon labelling \\
\hline Increase legumes in sward & $\begin{array}{l}\text { Restrictions on point of sale } \\
\text { mixtures }\end{array}$ & Set as a cross-compliance measure & Agronomic training \\
\hline Restore degraded land & Set quality criteria on land purchase & Land improvement grants & Market in land use permits \\
\hline $\begin{array}{l}\text { Integrated farm } \\
\text { management }\end{array}$ & Limit on farm animal grazing & Set carbon price & Integrate decision support tools \\
\hline $\begin{array}{l}\text { Improved feed and } \\
\text { roughage }\end{array}$ & $\begin{array}{l}\text { Set upper limits on stocking } \\
\text { intensity }\end{array}$ & Support for alternatives & Dietary calculators \\
\hline Genetically modified crops & Deregulation/competition policy & Directed R\&D/food safety & Food labelling \\
\hline More mixed farming & Limits on specialisation & Grants for mixed farming & Climate smart monitor farms \\
\hline
\end{tabular}

environment. Ultimately, there are a range of techniques and technologies which move towards this dual horizon of ensuring sustainability and allowing greater yield growth. Enabling this potential, by optimising policy to accelerate movement towards full-scale technical potential, requires significant investment and restructuring of regulatory frameworks. Hence, whilst a normative framework can be developed full-scale technical potential does not seem achievable purely through the mechanism of investment in research and technology. This is because there are significant barriers, uncertainties and sensitivities in the application of these technologies throughout the global food system. Furthermore, knowledge of the interaction of these technologies within a heterogeneous farming system is somewhat limited and context dependant (MacLeod et al. 2010; MacLeod 2015). Prescribing region-specific solutions is therefore limited by the biophysical, as well as the sociopolitical characterisation of these regions. In addition to the stochastic nature of farming, the diversity of opinion towards production and the concentration of market power along the food supply chain presents high hurdles to market-led economies wishing to develop cooperation along a supply chain.

Sustainable intensification is mostly focused on land scarcity. This is no surprise as the main driver behind SI's popularity has been the golden thread of "feeding a population of 9 billion and upward in 2050 on limited agricultural land". However, traditionally the uptake of technologies implies a substitution of labour with capital. Encouraging the embodiment of human capital with respect to the knowledge and learning required to sustain a system and also allow adaptation should therefore be more prominent in the desired outcomes within the SI rhetoric.

\section{Conclusions}

Setting a clear goal for food security provides a horizon and trajectory for research and food policy. A variety of supply side and demand side interventions can be employed to enable a shift from current adoption towards full-scale technical potential. Modelling and measurement of impacts within target regions should be assisted by the application of the framework proposed here to screen interventions before detailed cost-effectiveness and reductions of social risk be estimated. Applying the framework across both developed and developing regions should provide a range of mixtures for regional intervention logic.

However, whilst conceptually appealing, designing the optimal mix of interventions which moves food production forward is complicated by temporal shifts in the policy environment and the institutional capacity needed to transform the food supply chain. In addition securing uptake of technologies which are both yield enhancing and meet other SI criteria would merit a highly demanding tranche of public expenditure. Recognition of these multiple dimensions and trade-offs of production policies will be a step towards this goal. Nevertheless, it is unclear, given the requirement to provide dynamic and optimised sets of enablers for farming, processors, suppliers, retailers and consumers, that clear goals such as feeding 9 billion people could ever be achieved without complimentary 
policies in other sectors and interventions on the demand side.

Acknowledgments We acknowledge the financial support of the European Commission Animal Change project (contract no. KBBE266018) (http://www.animalchange.eu/). This paper was written under funding from the Scottish Government strategic research programme on Food.

Open Access This article is distributed under the terms of the Creative Commons Attribution 4.0 International License (http://crea tivecommons.org/licenses/by/4.0/), which permits unrestricted use, distribution, and reproduction in any medium, provided you give appropriate credit to the original author(s) and the source, provide a link to the Creative Commons license, and indicate if changes were made.

\section{References}

Alston JM, Marra MC, Pardey PG, Wyatt TJ (2000) Research returns redux. A meta-analysis of the returns to agricultural R\&D. Aust J Agric Resour Econ 44:185-215. doi:10.1111/1467-8489.00107

Anderson D, Clark C, Foxon TJ, Gross R, Jacobs M (2001) Innovation and the environment: challenges and policy options for the UK. Imperial College Centre for Energy Policy and Technology and the Fabian Society, London. doi:10.1016/j. enpol.2004.04.011

Antle JM, Diagana B (2003) Creating incentives for the adoption of sustainable agriculture practices: the role of carbon sequestration. Am J Agric Econ 85:1178-1184. doi:10.1111/j.0092-5853. 2003.00526.x

Barnes AP (2002) Public Agricultural R\&D and 'Social' total factor productivity. Agric Econ 27:65-74. doi:10.1016/s01695150(01)00061-5

Barnes AP (2012) Applying the concept of sustainable intensification in Scotland. Rural Policy Centre Discussion Paper. SRUC, Edinburgh. http://www.sruc.ac.uk/downloads/download/187/ 2012_sustainable_intensification_in_scotland. Accessed 8 Dec 2015

Barnes AP, Poole CEZ (2011) Applying the concept of sustainable intensification to Scottish Agriculture. Paper presented at the 86th annual conference of the agricultural economics society, Warwick, 2-4th April 2014. doi:10.1111/j.1477-9552.2011. 00318.x

Barnes AP, Thomson SG (2014) Deriving an index of sustainable intensification: how far can secondary data go. Ecol Indic 36:213-220. doi:10.1016/j.ecolind.2013.07.001

Barnes AP, Toma L (2012) A typology of dairy farmer perceptions towards climate change. Clim Chang 112:507-522. doi:10.1007/ s10584-011-0226-2

Barnes AP, Willock J, Toma L (2013) Comparing a 'budge' to a 'nudge': farmer responses to voluntary and compulsory compliance in water quality management regimes. J Rural Stud 32:448-452. doi:10.1016/j.jrurstud.2012.09.006

Barraclough PB, Howarth JR, Jones J, Lopez-Bellido R, Parmar S, Shepherd CE, Hawkesford MJ (2010) Nitrogen efficiency of wheat: genotypic and environmental variation and prospects for improvement. Eur J Agron 33:1-11. doi:10.1016/j.eja.2010.01. 005

Baulcombe D, Crute I, Davies B, Dunwell J, Gale M, Jones J, Pretty J, Sutherland W, Toulmin C (2009) Reaping the benefits: science and the sustainable intensification of global agriculture. The Royal Society, Policy document 11/09, London. https:// royalsociety.org/ /media/Royal_Society_Content/policy/publi cations/2009/4294967719.pdf. Accessed 8 Dec 2015

Baumgart-Getz A, Prokopy LS, Floress K (2012) Why farmers adopt best management practice in the United States: a meta-analysis of the adoption literature. J Environ Manage 96:17-25. doi:10. 1016/j.jenvman.2011.10.006

Beddington J, Asaduzzaman M, Clark M, Fernandez A, Guillou M, Jahn M, Erda L, Mamo T, Van Bo N, Nobre CA, Scholes R, Sharma R, Wakhungu J (2012) Achieving food security in the face of climate change: Final report from the Commission on Sustainable Agriculture and Climate Change. CGIAR Research Program on Climate Change, Agriculture and Food Security (CCAFS). Copenhagen, Denmark. https://cgspace.cgiar.org/bit stream/handle/10568/35589/climate_food_commission-finalmar2012.pdf?sequence $=1$. Accessed 8 Dec 2015

Brain R, Hostetler M, Irani T (2014) Why do cattle ranchers participate in conservation easement agreements? Key motivators in decision making. Agroecol Sustain Food Syst 38:299-316. doi:10.1080/21683565.2013.819479

Burton R, Kuczera C, Schwarz G (2008) Exploring farmers' cultural resistance to voluntary AES. Sociol Rural 48:16-37. doi:10. 1111/j.1467-9523.2008.00452.x

Chavas P, Holt MT (1990) Acreage decisions under risk: the case of corn and soybeans. Am J Agric Econ 72:529-538. doi:10.2307/ 1243021

Committee on Climate Change (2012) Reducing emissions in Scotland-first progress report. CCC, London. https://d2kjx2p8nxa8ft. cloudfront.net/wp-content/uploads/2013/03/1674_CCC_ScotsReport_bookmarked_2.pdf. Accessed 8 Dec 2015

Cordell D, Drangert J-O, White S (2009) The story of phosphorus: global food security and food for thought. Glob Environ Chang 19:292-305. doi:10.1016/j.gloenvcha.2008.10.009

Elliott J, Firbank LG, Drake B, Cao Y, Gooday R (2013) Exploring the concept of sustainable intensification. Land Use Policy Group, London. doi:10.1016/j.gloenvcha.2008.10.009

European Commission (2013) Overview of CAP Reform 2014-2020. Agricultural Policy Perspectives Brief No. 5. December 2013. http://ec.europa.eu/agriculture/policy-perspectives/policy-briefs/ 05_en.pdf. Accessed 8 Dec 2015

FAO (2010a) "Climate-Smart" agriculture: policies, practices and financing for food security, adaptation and mitigation. Hague Conference on Agriculture, Food Security and Climate Change. 31st October-5th November 2010. Food and Agriculture Organisation, Rome. http://www.fao.org/docrep/013/i1881e/ i1881e00.pdf. Accessed 8 Dec 2015

FAO (2010b) Sustainable crop production intensification through an ecosystem approach and an enabling environment: capturing efficiency through ecosystems services management. Committee on Agriculture. 22nd Session, Rome, 16-19th June 2010. http://www. fao.org/docrep/meeting/018/k8079e01.pdf. Accessed 8 Dec 2015

FAO (2011) An ecosystem approach to sustainable crop production intensification: a conceptual approach, Working Paper. Food and Agriculture Organisation, Rome. http://www.fao.org/fileadmin/ templates/agphome/scpi/SCPI_Compendium/SCPIConceptual_ framework.pdf. Accessed 8 Dec 2015

Fischer AR, van Dijk H, de Jonge J, Rowe G, Frewer LJ (2013) Attitudes and attitudinal ambivalence change towards nanotechnology applied to food production. Public Underst Sci 22:817-831. doi:10.1177/0963662512440220

Fish R, Lobley M, Winter M (2013) A license to produce? Farmer interpretations of the new food security agenda. J Rural Stud 29:40-49. doi:10.1016/j.jrurstud.2012.02.002

Foresight (2011) The future of food and farming: challenges and choices for global sustainability. The Government Office for Science, London. doi:10.1017/s207863361100021x 
Franks JR (2014) Sustainable intensification: a UK perspective. Food Policy 47:71-80. doi:10.1016/j.foodpol.2014.04.007

Fuglie K, Wang SL, Ball VE (eds) (2012) Productivity growth in agriculture: an international perspective. $\mathrm{CAB}$ International, Oxfordshire. doi: $10.1079 / 9781845939212.0000$

Garnett T, Appleby MC, Balmford A, Bateman IJ, Benton TG, Bloomer P, Burlingame B, Dawkins M, Dolan L, Fraser D, Herrero M, Hoffmann I, Smith P, Thornton PK, Toulmin C, Vermeulen SJ, Godfray HCJ (2013) Sustainable intensification in agriculture, premises and policies. Sci Policy Forum 341:33-34. doi:10.1126/science. 1234485

Godfray HCJ, Beddington JR, Crute IR, Haddad L, Lawrence D, Muir JF, Pretty J, Robinson S, Thomas SM, Toulmin C (2010) Food Security the challenge of feeding 9 billion people. Science 327:812. doi:10.1126/science. 1185383

Gregory PJ, Ingram JSI, Brklacichi M (2005) Climate change and food security. Philos Trans R Soc B 360:2139-2148. doi:10. 1098/rstb.2005.1745

Guillem EE, Barnes AP (2013) Farmers perceptions of bird conservation and farming management at a catchment level. Land Use Policy 31:565-575. doi:10.1016/j.landusepol.2012.09.002

Haden VR, Niles MT, Lubell M, Perlman J, Jackson LE (2012) Global and local concerns: what attitudes and beliefs motivate farmers to mitigate and adapt to climate change? PLoS ONE. doi:10.1371/journal.pone.0052882

Hagendijk R, Irwin A (2006) Public deliberation and governance: engaging with science and technology in contemporary Europe. Minerva 44:167-184. doi:10.1007/s11024-006-0012-x

Hamprecht J, Corston D, Noll M, Meier E (2005) Controlling the sustainability of food supply chains. Supply Chain Manage Int J 10:7-10. doi:10.1108/13598540510578315

Hanspach J, Abson DJ, Loos J, Tichit M, Jahi-Chappell M, Fischer J (2013) Develop then intensify. Science 341:713. doi:10.1126/ science.341.6147.713-a

Hertel TW, Ramankutty N, Baldos ULC (2014) Global market integration increases likelihood that a future African Green Revolution could increase crop land use and $\mathrm{CO}_{2}$ emissions. PNAS 111(38):13799-13804. doi:10.1073/pnas.1403543111

Hurley TM, Rao X, Pardey PG (2014) Re-examining the reported rates of return to food and agricultural R\&D. Am J Agric Econ 96:1492-1504. doi:10.1093/ajae/aau047

Islam M, Barnes AP, Toma L (2013) Climate Change scepticism among farmers. J Environ Psychol 34:137-150. doi:10.1016/j. jenvp.2013.02.002

Just RE, Pope RD (eds) (2002) A comprehensive assessment of the role of risk in US agriculture. Kluwer, Norwell. doi:10.1016/ s0169-5150(03)00041-0

Just RE, Zilberman D (1983) Stochastic structure, farm size and technology adoption in developing agriculture. Oxf Econ Pap 35:307-328. doi:10.1093/oxfordjournals.oep.a028610

Keating BA, Carberry PS, Bindraban PS, Senthold A, Meinke H, Dixon J (2010) Eco-efficient agriculture: concepts, challenges and opportunities. Crop Sci 50:109-119. doi:10.2135/cropsci2009.10.0594

Leat P, Lamprinopoulou C, Revoredo-Giha C, Kupiec-Teahan B (2011) Agri-food supply chains and sustainability related issues: evidence from across the Scottish agri-food economy. Contributed paper presented at the 85th Annual Conference of the Agricultural Economics Society, Warwick University, 18-20 April. doi: http://dx.doi.org/10.3390/su3040605

MacLeod M, Eory V, Gruère G, Lankoski J (2015) Cost-effectiveness of greenhouse gas mitigation measures for agriculture: a literature review. OECD Food, Agriculture and Fisheries Papers, No. 89, OECD Publishing, Paris. doi:10.1787/5jrvvkq900vj-en

MacLeod M, Moran D, Eory V, Rees RM, Barnes AP, Topp CFE, Ball B, Hoad S, Wall E, McVittie A, Pajot G, Matthews R, Smith P, Moxey A (2010) Developing greenhouse gas marginal abatement emissions from crops and soils in the UK. Agric Syst 103:198-209. doi:10.1016/j.agsy.2010.01.002

Matson PA, Parton WJ, Power AG, Swift MJ (1997) Agricultural intensification and ecosystem properties. Science 277(5325):504-509. doi:10.1126/science.277.5325.504

Maye D, Kirwan J (2013) Food security: a fractured consensus. J Rural Stud 29:1-6. doi:10.1016/j.jrurstud.2012.12.001

Misselhorn A, Aggarwal P, Ericksen P, Gregory P, Horn-Phathanothai L, Ingram J, Wiebe K (2012) A vision for attaining food security. Curr Opin Environ Sustain 4:7-17. doi:10.1016/j. cosust.2012.01.008

Moran D, Lucas A, Barnes AP (2013) Mitigation win-wins. Nat Clim Chang 3:611-613. doi:10.1038/nclimate1922

Nuffield Council on Bioethics (2007) Public health: the ethical issues. Nuffield Council on Bioethics, London. http://nuffieldbioethics. org/wp-content/uploads/2014/07/Public-health-ethical-issues. pdf. Accessed 8 Dec 2015

OECD (2011) A green growth strategy for food and agriculture. Preliminary report. OECD, Paris. http://www.oecd.org/green growth/sustainable-agriculture/48224529.pdf. Accessed 8th Dec 2015

Oerke E-C (2006) Crop losses to pests. J Agric Sci 144:31-43. doi:10. $1017 / \mathrm{s} 0021859605005708$

Olesen JE, Bindi M (2002) Consequences of climate change for European agricultural productivity, land use and policy. Eur J Agron 16:239-262. doi:10.1016/s1161-0301(02)00004-7

Parry MAJ, Reynolds M, Salvucci ME, Raines C, Andralojc PJ, Zhu X-G, Price GD, Condon AG, Furbank R (2011) Raising yield potential of wheat: increasing photosynthetic capacity and efficiency. J Exp Bot 62:453-468. doi:10.1093/jxb/erq304

Pezzey JCV (1997) Sustainability constraints versus "optimality" versus intertemporal Concern, and axioms versus data. Land Econ 73(4):448-466. doi:10.2307/3147239

Pretty J (2008) Agricultural sustainability: concepts, principles and evidence. Philos Trans R Soc B Biol Sci 363:447-465. doi:10. 1098/rstb.2007.2163

Pretty J, Toulim C, Williams S (2011) Sustainable intensification: increasing productivity in African food and agricultural systems. International Journal Agricultural Sustainability Series, Earthscan, UK. doi:10.1017/s0014479711001025

Prokopy LS, Floress K, Klotthor-Weinkauf D, Baumgart-Getz A (2008) Determinants of agricultural best management practice adoption: evidence from the literature. J Soil Water Conserv 63:300-311. doi:10.2489/63.5.300

Rehman T, Yates CM, McKemey K, Garforth C, Cooke RJ, Tranter RB, Park JR, Dorward PT (2003) Modelling the uptake of new technologies on dairy farms in South West England using the Theory of Reasoned Action and Mathematical Programming. A Contributed Paper Presented at the Agricultural Economics Society Conference, Seale Hayne, England, April 2003, p 37

Rorstad P, Vatn A, Kvavvestad V (2007) Why do transaction costs of agricultural policies vary? Agric Econ 36:1-11. doi:10.1111/j. 1574-0862.2007.00172.x

Rosegrant MW, Zhu T, Msangi S, Sulser T (2008) Global scenarios for biofuels: impacts and implications. Appl Econ Perspect Policy 30:495-505. doi:10.1111/j.1467-9353.2008.00424.x

Rosenzweig C, Iglesias A, Yang XB, Epstein PR, Chivian E (2001) Climate Change and Extreme Weather Events; Implications for Food Production, Plant Diseases, and Pests. Glob Chang Hum Health 2:90-104. doi:10.1023/a:1015086831467

Sage C (2012) Addressing the Faustian Bargain of the Modern Food System: connecting sustainable agriculture with sustainable consumption. Int J Agric Sustain 10:204-207. doi:10.1080/ 14735903.2012.690958

Scarpellini E, Sassatelli R, Banterle A, Olperle A (2013) Essential $\mathrm{SSH}$ research for the societal challenge: food security, 
sustainable agriculture \& forestry. League of European Research Universities, Leuvan, Belgium. http://leru.blogg.lu.se/files/2015/ 06/LERU-Note-2013-Essential-SSH-Research-for-the-SocietalChallenge-Food-security-sustainable-agriculture-and-forestry. pdf. Accessed 8 Dec 2015

Siebert R, Toogood M, Knierim A (2006) Factors affecting European farmers' participation in biodiversity policies. Sociol Ruralis 46:318-340. doi:10.1111/j.1467-9523.2006.00420.x

Smith G, Martindale W (2010) Food supply chains-our current understanding. In: Martindale W (ed) Aspects of applied biology 102 delivering food security with supply chain led innovations: understanding supply chains, providing food security, delivering choice, published by the Association of Applied Biologists. Warwick, The Warwick Enterprise Park, Wellesbourne, pp 75-79

Smith P, Martino D, Cai Z, Gwary D, Gwary D, Janzen H, Kumar P, McCarl B, Ogle S, O’Mara F, Rice C, Scholes B, Sirotenko O, Howden M, McAllister T, Pan G, Romanenkov V, Schneider U, Towprayoon S (2007) Policy and technological constraints to implementation of greenhouse gas mitigation options in agriculture. Agric Ecosyst Environ 118:6-28. doi:10.1016/j.agee.2006. 06.006

Smith P, Gregory PJ, van Vuuren D, Obersteiner M, Havlík P, Rounsevell M, Woods J, Stehfest E, Bellarby J (2010) Competition for land. Philos Trans R Soc B 365:2941-2957. doi:10. 1098/rstb.2010.0127

Tencalla F (2006) Science, politics, and the GM debate in Europe. Regul Toxicol Pharmacol 44:43-48. doi:10.1016/j.yrtph.2005. 04.011
Tilman D, Cassman KG, Matson PA, Naylor R, Polasky S (2002) Agricultural sustainability and intensive production practices. Nature 418:671-677. doi:10.1038/nature01014

Tomlinson I (2013) Doubling food production to feed the 9 billion, a critical perspective on a key discourse of food security in the UK. J Rural Stud 29:81-90. doi:10.1016/j.jrurstud.2011.09.001

Vermeulen SJ, Aggarwal PK, Ainslie A, Angelone C, Campbell BM, Challinor AJ, Hansen JW, Ingram JSI, Jarvis A, Kristjanson P, Lau C, Nelson GC, Thornton PK, Wollenberg E (2012) Options for support to agriculture and food security under climate change. Environ Sci Policy 15:136-144. doi:10.1016/j.envsci. 2011.09.003

Whitehead P, Parfitt J, Bojczuk K and James K (2013) Estimates of waste in the food and drink supply chain. Final report for WRAP. http://www.wrap.org.uk/sites/files/wrap/Estimates\% 20of $\% 20$ waste $\% 20$ in $\% 20$ the $\% 20$ food $\% 20$ and $\% 20$ drink $\% 20$ sup ply\%20chain_0.pdf. Accessed 30th May 2014

Wilson GA, Hart K (2000) Financial imperative or conservation concern? EU farmers' motivations for participation in voluntary agri-environmental schemes. Environ Plan A 32:2161-2185. doi:10.1068/a3311

Ye X, Al-Babili S, Klöti A, Zhang J, Lucca P, Beyer P, Potrykus I (2000) Engineering the provitamin A (beta-carotene) biosynthetic pathway into (carotenoid-free) rice endosperm. Science 287(5451):303-305. doi:10.1126/science.287.5451.303 